\title{
(2) OPEN ACCESS \\ SARS-CoV-2 on the ocular surface: is it truly a novel transmission route?
}

\author{
Xuhui Chen (D) , ${ }^{1}$ Huimin Yu (D) , ${ }^{1}$ Ting Mei, ${ }^{2}$ Bo Chen, ${ }^{1}$ Liwen Chen (D) , ${ }^{1}$ Shanling Li, ${ }^{2}$ \\ Xian Zhang, ${ }^{1}$ Xufang Sun (D) ${ }^{1}$
}

1 Department of Ophthalmology, Tongji Hospital, Tongji Medical College, Huazhong University of Science and Technology, Wuhan China

${ }^{2}$ Department of Nursing, Liyuan Hospital, Tongji Medical College, Huazhong University of Science and Technology, Wuhan, China

\section{Correspondence to}

Xufang Sun, Department of Ophthalmology, Tongji Hospital, Tongji Medical College, Huazhong University of Science and Technology, Jiefang Avenue 1095, Wuhan, Hubei Province, 430030, P.R. China; sunxufang2016@163.com

$\mathrm{XC}$ and $\mathrm{HY}$ contributed equally to this manuscript.

Received 7 March 2020

Revised 29 May 2020

Accepted 7 July 2020

Published Online First

11 August 2020

\section{Check for updates}

(c)Author(s) (or their employer(s)) 2021. Re-use permitted under CC BY-NC. No commercial re-use. See rights and permissions. Published by BMJ.

To cite: Chen $X$, Yu H, Mei T, et al. Br J Ophthalmol

2021:105:1190-1195.

\section{ABSTRACT}

Since December 2019, the novel COVID-19 outbreak has spread rapidly around the globe and infected millions of people. Although the major transmission route of severe acute respiratory syndrome coronavirus 2 (SARS-CoV-2) is considered to be airborne droplets and close contact, the ocular transmission route has been reported with great concern. The current work summarises the characteristics of SARS-CoV-2, the ocular distribution of the major SARSCoV-2 binding protein, and the experimental and clinical evidence of the ocular transmission route. Although it seems that the likelihood of the ocular surface being an infection gateway is low, SARS-CoV-2 infection or transmission via the ocular surface may cause conjunctivitis and other ocular discomfort. Therefore, good eye protection is an essential safeguard procedure, especially for medical staff.

\section{INTRODUCTION}

In early December 2019, a novel coronavirus (CoV), referred to as $2019-\mathrm{nCoV}$, became the infection source of the recent pandemic COVID-19. As of 29 May 2020, the total number of confirmed cases worldwide reached 5920 608, with 2574220 cured cases and 362431 deaths. This virus is a novel betacoronavirus $(\mathrm{BCoV})$ that resembles severe acute respiratory syndrome coronavirus (SARS-CoV). ${ }^{1}$ Therefore, the Coronavirus Study Group updated the virus to severe acute respiratory syndrome coronavirus 2 (SARS-CoV-2). ${ }^{2}$ Despite its rapid spread worldwide, the clinical characteristics of the SARS CoV-2 infection disease remain largely unclear. Generally, SARS-CoV-2-infected patients develop respiratory disorders and experience initial symptoms of fever, coughing and fatigue, which quickly progress to pneumonia. ${ }^{3}$ However, extra-pulmonary manifestations were observed in several patients at the onset of the illness, such as headache, diarrhoea, nausea and vomiting, ${ }^{4}$ and some patients presented with an asymptomatic infection. ${ }^{5}$ These issues pose great challenges to disease diagnosis and pandemic control, and necessitate a better understanding of SARS-CoV-2.

Similar to the transmission of SARS-CoV, the main spreading path of SARS-CoV-2 seems to be in close contact with an infected person and via airborne droplets or contact with fomite. ${ }^{6}$ The potential transmission routes include aerosol and gastrointestinal transmission. ${ }^{7}$ On 6 February 2020, Lu et $a l^{8}$ commented that the transmission of SARS-CoV-2 through the eyes must not be overlooked. Thereafter, numerous studies were performed to find evidence of this potential transmission route. There is a need for heightened investigations of SARS-CoV-2 binding protein expression on the ocular surface and a greater understanding of how ocular exposure routes influence disease presentation and progression in human beings.

\section{WHAT IS SARS-COV-2?}

The phylogenetic analysis showed that SARS-CoV-2 belongs to the bBCoV genera, which primarily infects mammals. The spike proteins $(\mathrm{S})$ are critical for the binding to host cell receptors and facilitate entry into host cells. In comparison with the full genomic sequences of SARS-CoV-2, BCoV sequences show 96.2\% similarity, which suggests that bats may be the zoonotic origin of SARS-CoV2. ${ }^{10}$ High-throughput sequencing and a real-time reverse-transcription PCR (RT-PCR) assay revealed that SARS-CoV-2 was closely related (88\%) to two bat-derived SARS-like CoVs, bat-SL-CoVZC45 and bat-SL-CoVZXC21, which were collected in 2018 in Zhoushan, eastern China. However, SARS-CoV2 was far from SARS-CoV (approximately 79\%) and Middle East respiratory syndrome coronavirus (MERS-CoV, approximately 50\%). ${ }^{1}$ Therefore, current evidence suggests that bats were likely the native hosts of SARS-CoV-2. Ji and colleagues ${ }^{11}$ suggested that snakes were another likely host for SARS-CoV-2, but this hypothesis was widely questioned. Further research is needed to determine the animal that was the intermediate host in the transmission cascade from bats to humans.

\section{MOLECULAR DIAGNOSIS OF SARS-COV-2}

An analysis of clinical samples from patients with new viral infections is critical for confirmation of their diagnosis. According to Koch's traditional hypothesis, virus isolation is the gold standard for the laboratory diagnosis of viruses. We summarised the different studies performed on the $\mathrm{CoV}$ based on $\mathrm{CoV}$ type, detection method, sample type and detection time (day after onset), and analysed whether the CoV infection was associated with conjunctivitis (table 1). We found that RT-PCR was the main laboratory method used for the diagnosing of $\mathrm{CoV}$ infection. Other methods, including ELISA and gene sequencing, are also very reliable. ${ }^{8} 12-14$

RT-PCR testing of conjunctival swabs was the most commonly used approach to determine the ocular characteristics of SARS-CoV-2-infected patients. However, the positive rate of the molecular diagnosis of tear viruses may be low. Ziad and 
Table 1 Detection methods for coronaviruses

\begin{tabular}{|c|c|c|c|c|c|}
\hline Coronavirus & Method & Sample & $\begin{array}{l}\text { Timing (days after } \\
\text { onset) }\end{array}$ & References & Conjunctivitis \\
\hline \multirow[t]{5}{*}{ SARS-CoV } & ELISA & Tear (conjunctival swabs) & $7-10$ days & 13 & $\begin{array}{l}\text { Not reported, but RT-PCR and ELISA detection of } \\
\text { patient's tears were positive. }\end{array}$ \\
\hline & PCR & Tear (conjunctival swabs) & 12 days & 21 & \\
\hline & RT-PCR & Blood serum & In the second week & 22 & \\
\hline & & Stool & & & \\
\hline & & Lung tissue & & & \\
\hline \multirow[t]{5}{*}{ SARS-CoV-2 } & RT-PCR & BALF & & & $\begin{array}{l}\text { Reported, RT-PCR conjunctival swab results were } \\
\text { positive in a small range of patients. }\end{array}$ \\
\hline & & Deep sputum & & 17 & \\
\hline & & Stool & 7 days & & \\
\hline & ELISA & Blood serum & $\begin{array}{l}\text { Acute phase, } \\
\text { remission phase }\end{array}$ & 13 & \\
\hline & Gene sequencing & Blood serum & & 12 & \\
\hline \multirow[t]{2}{*}{ HCoV-NL63 } & RT-PCR & Respiratory samples (nasal aspirates and swabs) & & 25 & Reported; no detection of eye tissue was reported \\
\hline & Gene sequencing & Nasopharyngeal aspirate specimen & 5 days & 14 & \\
\hline MERS-COV & RT-PCR & $\begin{array}{l}\text { Respiratory tract samples, such as nasopharyngeal } \\
\text { swab, sputum, deep tracheal aspirate, etc }\end{array}$ & & 26 & Not reported \\
\hline
\end{tabular}

BALF, bronchoalveolar lavage fluid; HCoV-NL63, human coronavirus NL63; MERS-CoV, Middle East respiratory syndrome coronavirus; RT-PCR, reverse-transcription PCR; SARS-CoV2, severe acute respiratory syndrome coronavirus 2 .

colleagues ${ }^{15}$ found that tracheal aspirates yielded significantly higher virus loads compared to nasopharyngeal swab and sputum specimens, which means that viral concentrations and genome fractions vary in different sites of the body. Tear samples came from the plasma, and their total concentration was small. The concentration of the virus in tears may be significantly lower than the respiratory samples. Chen and colleagues ${ }^{16}$ found that the viral RNA levels in conjunctival specimens were dramatically lower than the respiratory samples. Even pharyngeal swab PCR had a single positive rate of only approximately $30 \%$, and the positive rate for tears may be much lower. Therefore, it is challenging to detect SARS-CoV-2 on the ocular surface due to its lower viral load and limited sample volume.

To improve the sensitivity of molecular diagnosis methods, several other techniques are under development. Monoclonal antibodies, which use specific antibodies to recognise virus antigens in tears and blood, may be another sensitive detection method for the identification of SARS-CoV-2-related antigens. ${ }^{13}{ }^{17}$ RTloop-mediated isothermal amplification can also rapidly diagnose CoV. ${ }^{18}$ Broughton $e t a l^{19}$ recently uploaded a protocol for the detection of COVID-19 using CRISPR diagnostics online. However, this technique is not ready for clinical use. Therefore, collecting tears or conjunctival swabs for a series of molecular tests provides a more objective and accurate examination of whether the new virus will infect the eyes. Droplet digital PCR may help evaluate disease progression via the quantitative monitoring of viral load in lower respiratory tract samples. ${ }^{20}$

\section{HOW DOES SARS-COV-2 MAKE INDIVIDUALS INFECTIOUS?}

Notably, structural analyses suggest that SARS-CoV-2 enters host cells via ACE2 as the potential host receptor. ${ }^{27}$
Co-immunoprecipitation and ELISA also confirmed the binding of CD147 and SARS-CoV-2 spike protein. ${ }^{28}$ Therefore, cells expressing ACE2 or CD147 may be the potential targets for infection. Although ACE2 mRNA exists in almost all organs, its protein expression is largely unknown. Based on the rich knowledge of SARS-CoV and the new sequence of SARS-CoV-2, scientists analysed the potential receptor of SARS-CoV-2. ${ }^{29}$ Previous studies reported that SARS-S used ACE2 as an entry receptor and the cellular serine protease TMPRSS2 for S-protein priming. ${ }^{30} 31$ Despite replacing four of the five important interface amino acid residues, the SARS-CoV-2 S-protein had significant binding affinity for human ACE2. ${ }^{27}{ }^{32}$ Wan et $a l^{29}$ also reported that several critical residues in the SARS-CoV-2 receptor-binding motif (RBM) (particularly Gln493) provided favourable interactions with human ACE2, which is consistent with the capacity of SARS$\mathrm{CoV}-2$ for human cell infection. Several other residues in SARSCoV-2 RBM (particularly Asn501) are compatible with, but not ideal for, binding human ACE2, which suggests that SARS-CoV-2 acquired some capacity for human-to-human transmission. ${ }^{29}$ Therefore, ACE2 and TMPRSS2 currently represent the major players for cell entry. ${ }^{33} 34$ Ziegler $e t a l^{35}$ recently identified ACE2 and TMPRSS2 co-expressing cells in lung type II pneumocytes, ideal absorptive enterocytes and nasal goblet secretory cells. Their experiment data of viral infection in vitro and in vivo showed that SARS-CoV-2 exploited the species-specific interferon-driven upregulation of ACE2, which is a tissue-protective mediator during lung injury, to enhance infection. Sungnak et al similarly revealed that SARS-CoV-2 entry factors were highly expressed in nasal epithelial cells together with innate immune genes. ${ }^{36}$ Zhou et al ${ }^{37}$ also confirmed the expression of ACE2 and TMPRSS2 on ocular surface cells, including conjunctiva and cornea. 


\section{IS ACE2 PRESENT IN THE EYES?}

To determine the potential route of SARS-CoV-2 infection on the ocular surface, we summarised and analysed the distribution of ACE2 in eyes (table 2). SARS-CoV-2 has a stronger contagious characteristic than SARS-CoV, and its mechanism of human-tohuman spread may be related to ACE2. ${ }^{38}$ Sun et $a l^{39}$ found ACE2 expression in human cornea and conjunctival tissues, but its levels were lower than in heart and lung tissues. They also found that ACE2 expression in conjunctiva and corneal cells was primarily located in the cytoplasm and less expressed on the cell membrane. ${ }^{40}$ Several studies showed that an activator of ACE2, diminazene aceturate, was recently patented for the treatment of glaucoma and uveitis. However, the main sites of action may be the ciliary bodies, uvea, photoreceptor layer, outer and inner plexiform layers, ganglion cell layer and retinal pigment epithelial cells. ${ }^{4142}$ All of these results are evidence of ACE2 expression on the eye.

Zhou $e a^{37}$ analysed protein levels of ACE2 and TMPRSS2 in human postmortem eyes and surgical specimens. Across all eye specimens, immunohistochemical analysis revealed the expression of ACE2 in the conjunctiva, limbus and cornea, with especially prominent staining in the superficial conjunctival and corneal epithelial surface. Surgical conjunctival specimens also showed ACE2 expression in the conjunctival epithelium, which was especially prominent in the superficial epithelium and the substantia propria. All eye and conjunctival specimens also expressed TMPRSS2. ${ }^{37}$ Western blot analysis of protein lysates from human corneal epithelium obtained during refractive surgery confirmed the expression of ACE2 and TMPRSS2. Their results revealed that ocular surface cells, including conjunctiva, were susceptible to SARS-CoV-2 infection, and these cells may serve as a portal for entry and reservoir for person-to-person transmission of this virus.

\section{IS CD147 DISTRIBUTED IN THE EYES?}

CD147, also known as Basigin or extracellular matrix metalloproteinase inducer, is a transmembrane glycoprotein that is associated with viral infection. Previous studies showed that CD147 played a functional role in promoting SARS-CoV invasion into host cells. Chen and colleagues ${ }^{28}$ found that CD147 was a new SP receptor, and the interaction between CD147 and SP facilitates SARS-CoV-2 invasion of host cells. ACE2 and CD147 were also expressed on the ocular surface. Immunohistochemical studies showed that CD147 was detected in the epithelium and endothelium of the cornea, conjunctiva, corneal stromal cells and retinal pigment epithelial cells. ${ }^{47}$ CD147 is also expressed in human corneal epithelial cells and pigment epithelial cells, and it is present in tears, aqueous humour and vitreous fluids. ${ }^{47}$ CD147 plays a crucial role in the formation and maintenance of tissue epithelial structure in dry eye disease, and it may be essential for the formation and maintenance of an organised epithelial structure. ${ }^{48}$ CD147 is primarily expressed in the basal cells in the meibomian gland of the human eye, and it plays an important role in the differentiation and structural integrity of the meibomian gland. CD147 also plays an important role in the regulation of meibomian gland function. ${ }^{49}$ A unique distribution of lactate transporters is found in the retinal pigment epithelium, and these transporters regulate lactate levels of the outer retina. ${ }^{50}$ These results provide a molecular basis for the propagation of SARSCoV-2 through the ocular surface. Table 3 displays the distribution of CD147 in human eyes.

\section{IS SARS-COV-2 TRANSMITTED AND INFECTED THROUGH THE OCULAR SURFACE?}

Respiratory viruses cause a broad spectrum of diseases in humans, including several ocular tropisms. The main reason is that infectious droplets and body fluids easily contaminate the human conjunctival epithelium. ${ }^{51}$ Notably, hand-eye contact may increase the risk of contracting the virus from the hand. Therefore, we analysed the probability of an ocular transmission route.

\section{Link between the ocular and respiratory systems}

Several anatomical properties indicate the eye as a potential site of virus infection and a gateway for respiratory infection. The nasolacrimal system provides a significant anatomical bridge between the ocular and respiratory systems. ${ }^{52}$ Based on this bridge, tear fluid from the ocular surface is transported to the inferior meatus of the nose, which facilitates viral movement from the ocular surface to the respiratory tract. The ocular mucosal immune system and nasolacrimal ducts further share immunological interdependence. ${ }^{53}$ As previously reviewed, ${ }^{54}$ beyond the anatomical relationship between the ocular and respiratory systems, the structure and distribution of the cellular receptors in these systems likely contribute to the tissue tropism of respiratory viruses, such as when host epithelial cell

Table 3 Distribution of extracellular matrix metalloproteinase inducer (EMMPRIN; CD147) in human eyes

\begin{tabular}{llll}
\hline Position & & & References \\
\hline Anterior eye & Tear & 47 \\
& Aqueous humour & 47 \\
& Cornea & 47 \\
& Conjunctiva & & 4748 \\
& & Meibomian gland & 49 \\
\hline Posterior eye & Retina & & 47 \\
& & RPE & 50 \\
\hline & & Nerve fibres in optic nerve head & 47 \\
\hline & Vitreous body & & 47 \\
\hline
\end{tabular}

$R P E$, retinal pigment epithelium.

\begin{tabular}{|c|c|c|c|c|c|c|c|c|c|c|c|}
\hline & \multicolumn{3}{|c|}{ Anterior eye } & \multirow[b]{2}{*}{$\begin{array}{l}\text { Ciliary } \\
\text { body }\end{array}$} & \multirow[b]{2}{*}{$\begin{array}{l}\text { Vitreous } \\
\text { body }\end{array}$} & \multicolumn{5}{|c|}{ Posterior eye } & \multirow[b]{2}{*}{ References } \\
\hline & $\begin{array}{l}\text { Aqueous } \\
\text { humour }\end{array}$ & Cornea & Conjunctiva & & & Retina & $\begin{array}{l}\text { Retinal pigment } \\
\text { epithelium cells }\end{array}$ & $\begin{array}{l}\text { Photoreceptor } \\
\text { layer }\end{array}$ & $\begin{array}{l}\text { Outer and inner } \\
\text { plexiform layers }\end{array}$ & $\begin{array}{l}\text { Ganglion } \\
\text { cell layer }\end{array}$ & \\
\hline Rat & & & & + & & + & + & + & + & + & 4246 \\
\hline Rabbit & & + & + & & & & & & & & 3944 \\
\hline
\end{tabular}


glycoproteins bearing terminal sialic acids are distributed throughout the human respiratory tract and ocular tissue. These factors indicate that other ocular discharges containing the virus may drain to the respiratory tract through the lacrimal passage and cause the patient to become infected with pneumonia. Qing et $a l^{55}$ discussed that the virus entered the tears through droplets that may pass through the nasolacrimal ducts and into the respiratory tract. Despite intensive work focused on understanding the relationship between the ocular and respiratory systems, further research is needed to better understand the relationship between ocular and respiratory manifestations of SARS-CoV-2 infection.

\section{Virus infection on the ocular surface}

Ocular diseases associated with herpesvirus type 1 and feline calicivirus are not unusual in animals. Conjunctivitis, or 'pink eye', is the most commonly reported clinical symptom after virus infection on the ocular surface. Jean $e t a l^{56}$ found that conjunctivitis was the most common ocular condition, followed by corneal epithelial ulceration and keratitis with or without ulceration. However, ocular manifestations of feline $\mathrm{CoV}$ consist predominantly of uveitis and chorioretinitis with associated fibrinous exudate in the anterior ocular chamber. ${ }^{57}$ In humans, avian and human influenza A viruses show a capacity to use the eyes as a portal of entry and spread ocular disease. Like the respiratory tract, the ocular surface (notably the corneal and conjunctival epithelia) represents a mucosal surface that provides a pathway for viral entry. ${ }^{58}$ Other viruses that cause conjunctivitis in humans are also very common, such as the mumps virus, ${ }^{59}$ respiratory syncytial viruses ${ }^{60}$ and subtype $\mathrm{H} 7$ viruses. ${ }^{61}$ During the SARS outbreak, researchers also found that RT-PCR and ELISA detection of patient's tears were positive. ${ }^{13} 59$ Therefore, the ocular surface is actually quite vulnerable to respiratory viruses. In the SARS-CoV-2 epidemic area, SARS-CoV-2-related eye infections must be seriously and carefully evaluated.

\section{Animal model research of SARS-CoV, MERS-CoV and SARS-CoV-2 in the conjunctiva}

The study of mammalian models that recapitulate human disease has greatly improved our understanding of the pathological processes involved in infection and disease through ocular routes. Therefore, animal models were used to investigate the mechanism of SARS-CoV infection. Cynomolgus macaques were infected with SARS-CoV through the nostril and bronchus, the inferior conjunctival fornix of each eye or the saphenous vein, and their chest radiographs peaked between 8 and 10 days postinfection (dpi). Among the three groups, James and colleagues ${ }^{62}$ found that conjunctival-infected animals had more positive specimens than intravenous inoculation. However, there were some potential limitations to this study. First, there was only a small number of animals included in each group, and the entire spectrum of disease severity was not observed. Second, a relatively high inoculum of virus was used in the study. Nonetheless, these limitations did not affect our conclusions that the conjunctiva may be a route of transmission, although this route is less likely.

In a rhesus macaque model, the widespread dissemination of MERS-CoV occurred through the respiratory tract. MERS-CoV RNA was detected in the conjunctiva, but viral loads were no longer be detected in the conjunctiva 6 dpi. $^{63}$ This result suggests that the conjunctival scraping test should be performed as early as possible if ocular symptoms in a patient with COVID-19 or suspected case are identified.

Deng and colleagues ${ }^{64}$ recently found that macaques can be infected with SARS-CoV-2 via the conjunctival route. The viral load and distribution in the conjunctival infected-macaque were comparatively high in the nasolacrimal system but relatively mild and local in the lung compared to macaques that were inoculated via intratracheal routes, which provides strong evidence that conjunctivitis was the possible route for SARS-CoV-2 infection.

\section{Clinical data of SARS-CoV-2 infected on the ocular surface}

There have been a small number of reports of SARS-CoV2 -infected conjunctivitis. Table 4 summarises these studies by the number of patients (confirmed/suspect), number of patients with viral conjunctivitis, SARS-CoV-2 RNA tested in tears and/or conjunctival secretions, and conjunctival swabs sampling time (after the onset of SARS-CoV-2 infection).

The epidemiological data on the incidence of conjunctivitis in patients with COVID-19 range from $0.8 \%$ to $4.8 \% .{ }^{65-67}$ Few cases reported conjunctivitis as the initial medical presentation in patients with COVID-19. ${ }^{67}$ The ocular manifestations of SARS-CoV-2related conjunctivitis include conjunctival hyperaemia, ocular irritation, foreign body sensation, epiphora and chemosis. Wu et $a l^{68}$ found that these symptoms more commonly affected patients with severe systemic symptoms of COVID-19. Notably, the secretion of virus in tears always occurred during the early phase of the disease, which is similar to patients with SARS. ${ }^{21}$

Although positive SARS-CoV-2 RNA testing results in tears and/or conjunctival secretions are more likely to be found in patients with viral conjunctivitis, Xie $e t a l^{69}$ also reported two cases with strong positive SARS-CoV-2 testing results without conjunctivitis. Similarly, Zhou et $a l^{23}$ reported two probable positive cases with no symptoms of conjunctivitis. Therefore,

\begin{tabular}{|c|c|c|c|c|c|}
\hline No. & Reference detail & $\begin{array}{l}\text { Patients, } \mathrm{n} \\
\text { (confirmed/suspect) }\end{array}$ & $\begin{array}{l}\text { Patients with viral } \\
\text { conjunctivitis }(\mathrm{n})\end{array}$ & $\begin{array}{l}\text { SARS-CoV-2 RNA tested in tears } \\
\text { and/or conjunctival secretions }\end{array}$ & $\begin{array}{l}\text { Conjunctival swabs sampling time (after the } \\
\text { onset of SARS-CoV-2 infection) }\end{array}$ \\
\hline 1 & Zhou et $a^{23}$ & $67(64 / 3)$ & 1 & $\begin{array}{l}2 \text { Cases probable positive (negative } \\
\text { for the patients with conjunctivitis) }\end{array}$ & NA \\
\hline 2 & Zhang et $a l^{67}$ & $102(72 / 30)$ & 2 & 1 Case positive & Day 3 for CoV positive \\
\hline 3 & Xia et $a l^{66}$ & $30(30 / 0)$ & 1 & 1 Case positive & Days 2 and 5 (sampled twice for the same patient) \\
\hline 4 & Wu et $a l^{68}$ & $38(38 / 0)$ & 12 & 2 Cases positive & NA \\
\hline 5 & Chen et $\mathrm{al}^{16}$ & $1(1 / 0)$ & 1 & 1 Case positive & $\begin{array}{l}\text { Days } 13,14 \text { and } 17 \text { for CoV positive, Day } 19 \text { for CoV } \\
\text { negative }\end{array}$ \\
\hline 6 & Cheema et $a l^{70}$ & $1(1 / 0)$ & 1 & 1 Case weakly positive & Sampled on Day 5, tested on Day 7 \\
\hline 7 & Xie et $a l^{69}$ & $33(33 / 0)$ & 0 & 2 Cases strong positive & 1 Case on Day 4,1 case on Day 5 \\
\hline 8 & Li et $a l^{73}$ & $2(2 / 0)$ & 2 & 1 Case positive & 1 Case (positive) on Day 1, 1 case on Day 4 \\
\hline
\end{tabular}

SARS-CoV2, severe acute respiratory syndrome coronavirus 2. 
SARS-CoV-2 may exist in conjunctival eyes and on the normal ocular surface of patients with COVID-19, which suggests that SARS-CoV-2 is spread through conjunctival contact.

There are several cases where patients had conjunctivitis symptom, but the SARS-CoV-2 RNA testing of tears and/or conjunctival secretions were negative. The reason behind these results may be associated with the sampling time, the collection of few exfoliated cells and the lack of sensitivity of the RT-PCR kits.

Apart from conjunctivitis, patients may also develop other ocular discomfort or disease. Cheema et $a l^{70}$ reported a case where keratoconjunctivitis was the initial medical presentation. Hong et $\mathrm{al}^{71}$ recruited 56 confirmed patients to investigate detailed ocular symptoms, including eye itching, sore eye, dry eye and floaters. In their study, 15 (27\%) patients had aggravated ocular symptoms and $6(11 \%)$ patients had prodromal ocular symptoms before disease onset. Chen $e t a l^{72}$ recently performed a cross-sectional study of 534 cases with COVID-19 in Wuhan. Of the total 534 patients with COVID-19, conjunctival congestion (4.68\%), dry eye (112, 20.97\%), blurred vision (68, $12.73 \%)$ and foreign body sensation $(63,11.80 \%)$ ranked as the top four.

The recent results show that SARS-CoV-2 is capable of causing ocular complications. Ocular symptoms may appear just before the onset of respiratory symptoms. SARS-CoV-2 RNA testing is best performed in the early days after onset. Although no researches compared the disease outcomes of patients who were infected through ocular transmission route and respiratory transmission route, all of these clinical data showed that after topical antiviral treatment, pink eyes or conjunctivitis quickly return to normal. Therefore, we suspected that the patients infected through ocular transmission route might recover more quickly, and the disease outcomes are better than infected through respiratory transmission route.

\section{HOW DO YOU PROTECT AGAINST SARS-COV-2 INFECTION VIA THE OCULAR SURFACE?}

Wang et $a l^{74}$ recently reported that 138 hospitalised SARS-COV2-infected pneumonia cases had a hospital-associated transmission rate of $41 \%$, among whom $70 \%$ were healthcare professionals. The main risk factor for the nosocomial infection of medical staff members who provided nursing care to the intubated patients with SARS was whether they wore protective goggles $(1 \%$ of the clinicians wearing eye protection were infected versus $8 \%$ of the clinicians who did not). ${ }^{75}$ Considering the common feature of sporadic cases and the higher viral aerosol load in the hospital, the ocular transmission route in hospitals should be seriously considered. A lack of eye protection may lead to ocular surface exposure or facial skin exposure, which may then spread from the facial skin to the hands and other mucous membranes. Therefore, in addition to regular masks, gowns and gloves, goggles and frequent handwashing are essential protective measures, especially for medical staff in close contact with patients with COVID-19.

\section{CONCLUSION}

In conclusion, the main question in the present review was whether SARS-CoV-2 can infect or be transmitted through the ocular surface. We summarised the structure, molecular diagnostic methods and infection mechanisms of SARS-CoV-2, and presented a summary of the distribution of ACE2 and CD147 in eyes. Based on the anatomical features of the ocular and respiratory systems and the experimental and clinical evidence of
CoV-related ocular disease, we conclude that the likelihood of the ocular surface being an infection gateway is low, but SARSCoV-2 infection or transmission through the ocular surface may be a potential infection route, especially in hospitals. Therefore, good eye protection is an essential safeguard procedure, especially for medical staff. Only through this measure can healthcare professionals be better protected against non-combatant attrition.

Correction notice This paper has been amended since it was published. The following credit has been added: XC and HY contributed equally to this manuscript.

Contributors $\mathrm{XC}$ and $\mathrm{HY}$ participated in the research design, data acquisition/ research execution, data analysis/interpretation and manuscript preparation. TM, BC, LC and SL participated in the data acquisition and manuscript revision. XZ and XS supervised the manuscript.

Funding This work was supported by grants from the National Natural Science Foundation of P.R. China (Grant No. 81974136) and Huazhong University of Science and Technology (2020kfyXGYJ068).

Competing interests None declared.

Patient consent for publication Not required.

Provenance and peer review Not commissioned; externally peer reviewed.

Open access This is an open access article distributed in accordance with the Creative Commons Attribution Non Commercial (CC BY-NC 4.0) license, which permits others to distribute, remix, adapt, build upon this work non-commercially, and license their derivative works on different terms, provided the original work is properly cited, appropriate credit is given, any changes made indicated, and the use is noncommercial. See: http://creativecommons.org/licenses/by-nc/4.0/.

\section{ORCID iDs}

Xuhui Chen http://orcid.org/0000-0002-9791-2051

Huimin Yu http://orcid.org/0000-0002-2663-2167

Liwen Chen http://orcid.org/0000-0003-4705-4754

Xufang Sun http://orcid.org/0000-0001-7133-4508

\section{REFERENCES}

1 Lu R, Zhao X, Li J, et al. Genomic characterisation and epidemiology of 2019 novel coronavirus: implications for virus origins and receptor binding. Lancet 2020.

2 Gorbalenya AE, Baker SC, Baric RS, et al. Severe acute respiratory syndrome-related coronavirus: the species and its viruses: a statement of the Coronavirus Study Group. bioRxiv 2020;2020-2.

3 Huang C, Wang Y, Li X, et al. Clinical features of patients infected with 2019 novel coronavirus in Wuhan, China. Lancet 2020;395:497-506.

4 Chen N, Zhou M, Dong X, et al. Epidemiological and clinical characteristics of 99 cases of 2019 novel coronavirus pneumonia in Wuhan, China: a descriptive study. Lancet 2020.

5 Rothe C, Schunk M, Sothmann P, et al. Transmission of 2019-nCoV infection from an asymptomatic contact in Germany. N Engl J Med 2020;382:970-1.

6 Chan-Yeung M, Xu RH. SARS: Epidemiology. Respirology 2003;8:S9-14.

7 Liu Y, Ning Z, Chen Y, et al. Aerodynamic analysis of SARS-CoV-2 in two Wuhan hospitals. Nature 2020;582:557-60.

8 Lu C, Liu X, Jia Z. 2019-nCoV transmission through the ocular surface must not be ignored. Lancet 2020;395:e39.

9 Ceraolo C, Giorgi FM. Genomic variance of the 2019-nCoV coronavirus. J Med Virol 2020;92:522-8.

10 Zhou $P$, Yang XL, Wang XG, et al. A pneumonia outbreak associated with a new coronavirus of probable bat origin. Nature 2020;579:270-3

11 Ji W, Wang W, Zhao X, et al. Homologous recombination within the spike glycoprotein of the newly identified coronavirus may boost cross-species transmission from snake to human. J Med Virol 2020

12 World Health Organization. Global Surveillance for human infection with novel coronavirus disease (COVID-19). 2020. Available https://www.who.int/publications-detail Iglobal-surveillance-for-human-infection-with-novel-coronavirus-(2019-ncov)

13 Cui W, Geriletu, Gao W, Liu W. Comparative study on specific antibody in tear and blood of SARS patients. Inner Mongolia Med J 2004;36:577-8.

14 van der Hoek L, Pyrc K, Jebbink MF, et al. Identification of a new human coronavirus. Nat Med 2004;10:368-73.

15 Memish ZA, Al-Tawfiq JA, Makhdoom HQ, et al. Respiratory tract samples, viral load and genome fraction yield in patients with middle east respiratory syndrome. J Infect Dis 2014;210:1590-4.

16 Chen L, Liu M, Zhang Z, et al. Ocular manifestations of a hospitalised patient with confirmed 2019 novel coronavirus disease. Br J Ophthalmol 2020;104:748-51. 
17 Corman VM, Landt O, Kaiser M, et al. Detection of 2019 novel coronavirus (2019-nCoV) by real-time RT-PCR. Euro Surveill 2020;25:3.

18 Huang WE, Lim B, Hsu CC, et al. RT-LAMP for rapid diagnosis of coronavirus SARS-CoV-2. Microb Biotechnol 2020;13:950-61.

19 Broughton JP, Deng X, Yu G, et al. CRISPR-Cas12-based detection of SARS-CoV-2. Nat Biotechnol 2020;38:870-4.

20 Yu F, Yan L, Wang N, et al. Quantitative detection and viral load analysis of SARS-CoV2 in infected patients. Clin Infect Dis 2020.

21 Loon SC, Teoh SC, Oon LL, et al. The severe acute respiratory syndrome coronavirus in tears. Br J Ophthalmol 2004;88:861-3.

22 Bermingham A, Heinen P, Iturriza-Gomara $\mathrm{M}$, et al. Laboratory diagnosis of SARS. Philos Trans R Soc Lond B Biol Sci 2004;359:1083-9.

23 Zhou Y, Zeng Y, Tong $Y$, et al. Ophthalmologic evidence against the interpersonal transmission of 2019 novel coronavirus through conjunctiva. medRxiv 2020;2020-2.

24 Holshue ML, DeBolt C, Lindquist S, et al. First case of 2019 novel coronavirus in the United States. New Engl I Med 2020;382:929-36.

25 Vabret A, Mourez T, Dina J, et al. Human coronavirus NL63, France. Emerg Infect Dis 2005;11:1225-9.

26 Yin Y, Wunderink RG. MERS, SARS and other coronaviruses as causes of pneumonia. Respirology 2018;23:130-7.

27 Hoffmann M, Kleine-Weber H, Krüger N, et al. The novel coronavirus 2019 (2019-nCoV) uses the SARS-coronavirus receptor ACE2 and the cellular protease TMPRSS2 for entry into target cells. bioRxiv 2020;2020-1.

28 Wang K, Chen W, Zhou Y, et al. SARS-CoV-2 invades host cells via a novel route: CD147-spike protein. bioRxiv 2020;2020-3.

29 Wan Y, Shang J, Graham R, et al. Receptor recognition by novel coronavirus from Wuhan: an analysis based on decade-long structural studies of SARS. J Virol 2020;94.

30 Glowacka I, Bertram S, Muller MA, et al. Evidence that TMPRSS2 activates the severe acute respiratory syndrome coronavirus spike protein for membrane fusion and reduces viral control by the humoral immune response. J Virol 2011:85:4122-34.

31 Shulla A, Heald-Sargent T, Subramanya G, et al. A transmembrane serine protease is linked to the severe acute respiratory syndrome coronavirus receptor and activates virus entry. J Virol 2011;85:873-82.

32 Xu X, Chen P, Wang J, et al. Evolution of the novel coronavirus from the ongoing Wuhan outbreak and modeling of its spike protein for risk of human transmission. Sci China Life Sci 2020.

33 Hoffmann M, Kleine-Weber H, Schroeder S, et al. SARS-CoV-2 cell entry depends on ACE2 and TMPRSS2 and is blocked by a clinically proven protease inhibitor. Cell 2020;181:271-80

34 Fodoulian L, Tuberosa J, Rossier D, et al. SARS-CoV-2 receptor and entry genes are expressed by sustentacular cells in the human olfactory neuroepithelium. bioRxiv 2020;2020-3.

35 Ziegler CGK, Allon SJ, Nyquist SK, et al. SARS-CoV-2 receptor ACE2 is an interferon-stimulated gene in human airway epithelial cells and is detected in specific cell subsets across tissues. Cell 2020;181:1016-1035.e19.

36 Sungnak W, Huang N, Becavin C, et al. SARS-CoV-2 entry factors are highly expressed in nasal epithelial cells together with innate immune genes. Nat Med 2020;26:681-7.

37 Zhou L, Xu Z, Castiglione GM, et al. ACE2 and TMPRSS2 are expressed on the human ocular surface, suggesting susceptibility to SARS-CoV-2 infection. bioRxiv 2020:2020-5

38 Tian HY. 2019-nCoV: new challenges from coronavirus. Zhonghua Yu Fang Yi Xue Za Zhi 2020;54:E1

39 Sun Y, Pan X, Liu L, et al. Expression of SARS coronavirus S protein functional receptor ACE2 in human and rabbit cornea and conjunctiva. Rec Adv Ophthalmol 2004:24:332-6.

40 Sun Y, Liu L, Pan X, et al. Mechanism of the action between the SARS-CoV S240 protein and the ACE2 receptor in eyes. Int I Ophthalmol Chi 2006:6:783-6.

41 Luhtala S, Vaajanen A, Oksala 0, et al. Activities of angiotensin-converting enzymes ACE1 and ACE2 and inhibition by bioactive peptides in porcine ocular tissues. $J$ Ocul Pharmacol Ther 2009:25:23-8.

42 Foureaux G, Nogueira JC, Nogueira BS, et al. Antiglaucomatous effects of the activation of intrinsic angiotensin-converting enzyme 2. Invest Ophthalmol Vis Sci 2013;54:4296-306.

43 Holappa M, Valjakka J, Vaajanen A. Angiotensin(1-7) and ACE2, "the hot spots" of renin-angiotensin system, detected in the human aqueous humor. Open Ophtha/mol J 2015:9:28-32.

44 Sun Y, Liu L, Pan X. Binding action between SARS-CoV S666 protein and ACE2 receptor in eyes. Rec Adv Ophthalmol 2007;27:250-3.

45 Senanayake P, Drazba J, Shadrach K, et al. Angiotensin II and its receptor subtypes in the human retina. Invest Ophthalmol Vis Sci 2007;48:3301-11.
46 Zheng C, Lei C, Chen Z, et al. Topical administration of diminazene aceturate decreases inflammation in endotoxin-induced uveitis. Mol Vis 2015;21:403-11. eCollection 2015.

47 Maatta M, Tervahartiala T, Kaarniranta K, et al. Immunolocalization of EMMPRIN (CD147) in the human eye and detection of soluble form of EMMPRIN in ocular fluids. Curr Eye Res 2006:31:917-24.

48 Huet E, Vallee B, Delbe J, et al. EMMPRIN modulates epithelial barrier function through a MMP-mediated occludin cleavage: implications in dry eye disease. Am J Pathol 2011;179:1278-86.

49 Mauris J, Dieckow J, Schob S, et al. Loss of CD147 results in impaired epithelial cell differentiation and malformation of the meibomian gland. Cell Death Dis 2015;6:e1726.

50 Deora AA, Philp N, Hu J, et al. Mechanisms regulating tissue-specific polarity of monocarboxylate transporters and their chaperone CD147 in kidney and retinal epithelia. Proc Natl Acad Sci U S A 2005;102:16245-50.

51 Olofsson S, Kumlin U, Dimock K, et al. Avian influenza and sialic acid receptors: more than meets the eye? Lancet Infect Dis 2005;5:184-8.

52 Paulsen F, Garreis F, Schicht M, et al. Anatomy and physiology of the nasolacrimal ducts. HNO 2016;64:354-66.

53 Chentoufi AA, Dasgupta G, Nesburn AB, et al. Nasolacrimal duct closure modulates ocular mucosal and systemic CD4(+) T-cell responses induced following topical ocular or intranasal immunization. Clin Vaccine Immunol 2010;17:342-53.

54 Belser JA, Rota PA, Tumpey TM. Ocular tropism of respiratory viruses. Microbiol Mol Biol Rev 2013;77:144-56.

55 Qing H, Li Z, Yang Z, et al. The possibility of COVID-19 transmission from eye to nose. Acta Ophthalmol 2020;98.

56 Stiles J. Ocular manifestations of feline viral diseases. Vet J 2014:201:166-73.

57 Doenges SJ, Weber K, Dorsch R, et al. Detection of feline coronavirus in cerebrospina fluid for diagnosis of feline infectious peritonitis in cats with and without neurological signs. J Feline Med Surg 2016;18:104-9.

58 Belser JA, Lash RR, Garg S, et al. The eyes have it: influenza virus infection beyond the respiratory tract. Lancet Infect Dis 2018;18:e220-7.

59 Kalkan A, Ozden M, Yilmaz T, et al. A case of mumps conjunctivitis: detection of the virus RNA by nested PCR in tear sample. Scand I Infect Dis 2004:36:697-700.

60 Fujishima H. Respiratory syncytial virus may be a pathogen in allergic conjunctivitis. Cornea 2002;21:S39-45.

61 Belser JA, Bridges CB, Katz JM, et al. Past, present, and possible future human infection with influenza virus A subtype H7. Emerg Infect Dis 2009;15:859-65.

62 Lawler JV, Endy TP, Hensley LE, et al. Cynomolgus macaque as an animal model for severe acute respiratory syndrome. PLoS Med 2006;3:e149.

63 de Wit E, Rasmussen AL, Falzarano D, et al. Middle East respiratory syndrome coronavirus (MERS-CoV) causes transient lower respiratory tract infection in rhesus macaques. Proc Natl Acad Sci U S A 2013:110:16598-603.

64 Deng W, Bao L, Gao H, et al. Rhesus macaques can be effectively infected with SARS-CoV-2 via ocular conjunctival route. bioRxiv 2020:2020-3.

65 Guan W, Ni Z, Hu Y, et al. Clinical characteristics of coronavirus disease 2019 in China. New Engl I Med 2020;382:1708-20.

66 Xia J, Tong J, Liu M, et al. Evaluation of coronavirus in tears and conjunctival secretions of patients with SARS-CoV-2 infection. J Med Virol 2020;92:589-94.

67 Zhang X, Chen X, Chen L, et al. The evidence of SARS-CoV-2 infection on ocular surface. Ocul Surf 2020;18:360-2.

68 Wu P, Duan F, Luo C, et al. Characteristics of ocular findings of patients with coronavirus disease 2019 (COVID-19) in Hubei Province, China. JAMA Ophthalmol 2020;138:575.

69 Xie HT, Jiang SY, Xu KK, et al. SARS-CoV-2 in the ocular surface of COVID-19 patients. Eye Vis (Lond) 2020;7:23.

70 Cheema M, Aghazadeh $\mathrm{H}$, Nazarali S, et al. Keratoconjunctivitis as the initial medical presentation of the novel coronavirus disease 2019 (COVID-19). Canadian J Ophthalmol 2020.

71 Hong N, Yu W, Xia J, et al. Evaluation of ocular symptoms and tropism of SARS-CoV-2 in patients confirmed with COVID-19. Acta Ophthalmol 2020.

72 Chen L, Deng C, Chen X, et al. Ocular manifestations and clinical characteristics of 534 cases of COVID-19 in China: a cross-sectional study. Acta Ophthalmol 2020

73 Li X, Wang M, Dai J, et al. Novel coronavirus disease with conjunctivitis and conjunctivitis as first symptom: two cases report. Chin J Exp Ophthalmol 2020;38:E002

74 Wang D, Hu B, C H, et al. Clinical characteristics of 138 hospitalized patients with 2019 novel coronavirus-infected pneumonia in Wuhan, China. JAMA 2020;323:1061

75 Raboud J, Shigayeva A, McGeer A, et al. Risk factors for SARS transmission from patients requiring intubation: a multicentre investigation in Toronto, Canada. Plos One 2010:5:e10717. 